\title{
A donation from the legacy of Sergije Dogan in the collections of the Croatian Academy of Sciences and Arts
}

\author{
Silvija Brkić Midžić ${ }^{1}$, Stella Fatović-Ferenčić \\ ${ }^{1}$ Croatian Museum of Medicine and Pharmacy, Croatian Academy of Sciences and Arts, Zagreb, Croatia \\ ${ }^{2}$ The Division for the History of Medical Sciences, The Institute of the History and Philosophy of Science, Croatian Academy \\ of Sciences and Arts, Zagreb, Croatia
}

OPEN ACCESS

Correspondence: Silvija Brkić Midžić hmmf@hazu.hr orcid.org/0000-0002-0096-5510

This article was submitted to RAD CASA - Medical Sciences as the original article

Conflict of Interest Statement: The authors declare that the research
was conducted in the absence of any commercial or financial relationships that could be construed as a potential conflict of interest.
cotial

Received: 27 October 2020 Accepted: 17 November 2020 Published: 28 December 2020

Citation: Brkić Midžić S, Fatović-Ferenčić S. A donation from the legacy of Sergije donation from the legacy of Sergije
Dogan in the collections of the CroaDogan in the collections of the Croa-
tian Academy of Sciences and Arts RAD CASA - Medical Sciences. 544=52-53 (2020): 98-104 DOI: https://dx.doi. org/10.21857/90836c700y

Copyright (C) 2020 Brkić Midžić S, Fatović-Ferenčić $\mathrm{S}$. This is an openaccess article distributed under the terms of the Creative Commons Attribution License (CC BY). The use, distribution or reproduction in other forums is permitted, provided the original author(s) and the copyright owners(s) are credited and that the original publication in this journal is cited, in accordance whit accepted adacemic practice. No use, distribution or reproduction is permitted which or reproduction is permitted which
does not comply with these terms.

\section{ABSTRACT:}

The legacy of the Croatian neurologist Sergije Dogan is preserved in two institutions of the Croatian Academy of Sciences and Arts, the Croatian Museum of Medicine and Pharmacy and the Division for the History of Medical Sciences. Dogan's legacy became part of the holdings of these institutions in 2019 thanks to his daughter Branka Marinović, head of the Clinic for Dermatovenerology at the Rebro Clinical Hospital Centre in Zagreb. The donated material is a rare example of preserved material evidence of one doctor's entire course of education, his clinical, scientific and teaching work, as well as his broader social activities. In this paper, we bring a preliminary statement on the content of the legacy, while the entire legacy will be presented in full at the exhibition due in 2021 and in the book within the publishing series Discussions and Materials for the History of Science of the Croatian Academy of Sciences and Arts.

KLJUČNE RIJEČI: Sergije Dogan - legacy; history of medicine; neurology; Croatia; $20^{\text {th }}$ century

\section{SAŽETAK:}

Donacija iz ostavštine Sergija Dogana u zbirkama Hrvatske aKademije znanosti i umjetnosti U dvjema ustanovama Hrvatske akademije znanosti i umjetnosti, Hrvatskom muzeju medicine i farmacije i Odsjeku za povijest medicinskih znanosti, čuva se ostavština hrvatskog neurologa Sergija Dogana. Ostavština Dogan postala je dijelom fundusa ovih ustanova 2019. godine zahvaljujući njegovoj kćeri Branki Marinović, predstojnici Klinike za dermatovenerologiju Kliničkoga bolničkog centra u Zagrebu. Darovana građa predstavlja rijedak primjer sačuvanoga materijalnog svjedočanstva o cjelokupnom tijeku obrazovanja, kliničkog, znanstvenog i nastavnog rada jednoga liječnika i o njegovu širem društvenom djelovanju. U ovom radu donosimo preliminarno priopćenje o sadržaju ostavštine, dok će se sveukupna ostavština u cijelosti predstaviti na izložbi koja će biti postavljena 2021. i u knjizi unutar nakladničkog niza Rasprave i grada za povijest znanosti Hrvatske akademije znanosti i umjetnosti koja se predviđa za 2022. godinu.

KLJUČnE RIJEČI: Sergije Dogan - ostavština; povijest medicine; neurologija; Hrvatska; 20. stoljeće 


\section{INTRODUCTION}

Among its numerous activities, the Division for the History of Medical Sciences of the Institute of History and Philosophy of Science at the Croatian Academy of Sciences and Arts, has been collecting various materials for the history of biomedical sciences and has been preserving them for decades. This gradually turned into a collection of the Museum of the History of Medicine and Pharmacy, at the core of which are integrated collections from the Institute of the History of Pharmacy and the Museum of the History of Health Care within the Croatian Medical Association. ${ }^{1,2}$ For many years, the department took care of this valuable material, used it in university teaching for the subjects related to the history of medicine and pharmacy, and occasionally presented it to the public at exhibitions and in various publications, until the idea matured that a specialized museum should be established, which would deal with the collection, protection, documentation and communication of Croatian medical and pharmaceutical heritage. This proposal, made by the Head of the Division Stella Fatović-Ferenčić, was first referred to the Management Board of the Academy in 2006, and was then supported by the Department of Medical Sciences. Finally, on May 16, 2011 the Initial Committee for the Establishment of the Croatian Museum of the History of Medicine and Pharmacy, headed by Member of the Academy Marko Pećina, the then Secretary of the Department, held a meeting and a final decision was made to launch the Museum project. ${ }^{3,4}$

The Croatian Museum of Medicine and Pharmacy was established following a decision of the Ministry of Culture of the Republic of Croatia on July 7, 2014, and began operating on March 2, 2015 when the senior curator and director Silvija Brkić Midžić took over its management. New donations of museum material soon began to arrive, and during the first marketing, promotional, exhibition and publishing activities, a wide circle of Museum friends were brought together - institutions, companies and individuals who contributed to the development of the project in various ways. ${ }^{5}$ Thanks to the support of professional, scientific and broader society, in the first five years of its operation, the Museum produced complete project documentation for the reconstruction and renovation of the former printing house with an area of about $350 \mathrm{~m}^{2}$ on the ground floor of the Academy building in 24 Gundulićeva Street in Zagreb, as well as the arrangement for a permanent exhibition. Based on the approved museological concept, the permanent exhibition scenario was prepared in which a brief overview of the history of Croatian medicine and pharmacy was to be interpreted, emphasizing certain topics, persons and subjects, and containing four separate units: a room for occasional exhibitions about prominent Croatian doctors and pharmacists; a room for exhibiting old pharmacy furniture with pharmaceutical items and equipment, and a room intended for various branches of medicine, which would be reorganised every few years. Furthermore, the plan is also to set up a multimedia research room. Considering the given spatial framework, the Museum's permanent exhibition was to include a small part of the material, while other museum items would be presented in occasional exhibitions, publications and other media.

According to the census concluded on March 20, 2020, the Museum's holdings now contain 5,028 items, of which 3,149 were taken from the Division for the History of Medical Sciences, while 1,879 items were collected through donations between March 1, 2015 and March 20, 2020.7 In addition to the collection of the Otorhinolaryngology Clinic in Šalata, which was donated to the Museum by the Zagreb School of Medicine, there have been several donations from various medical institutions and individual items of medical and pharmaceutical heritage, but mostly these are donations from personal collections or family legacies of Croatian doctors and pharmacists, such as Hrvoje Tartalja ${ }^{8}$, Gustav Porschinsky, Pavao Primorac, Lujo Naletilić, Goran Ivanišević, Bosiljka Cvetnić; the Kallay-Matković family of dentists, Vladimir Milas, Vladimir Dugački, the IlakovacEfendić family of pharmacists', Drago Novak, Ivo Padovan, Ranko Mladina, Svetko Fatović, Sergije Dogan, and others. The Division's archives already contain the legacies of prominent Croatian pharmacists and doctors; for example, the legacy of the Croatian Pharmaceutical Society includes the collections of Hinko Brodjovin, Julije Domac, the family of Eugen Viktor Feller, and others. Medical legacies include donations from the families of doctors Dürrigl, Durst, Kogoj, Dogan, Špišić, Florschütz, and others. ${ }^{10}$

We know from the history of pharmacy that in Croatia it was almost a rule for several generations of the same family to be engaged in pharmacy, which yielded the emergence of something like "pharmacy dynasties", such as the families Panac, Seitz, Csillagh, Krauterblüth-Krajanski, Pečić, Vouk, Deszathy, ${ }^{11}$ KubanyiRenaldy-Barković ${ }^{12}$, and others. However, not many people know that there are also numerous families who produced two or more generations of doctors each. Among them is the Dogan Family. Sergije Dogan (1916 - 1979) (Figure 1) was married to pediatrician Kate Dogan-Librenjak (1923 - 1979) (Figure 2) and they had a daughter Branka, married name Marinović, today head of the Clinic for Dermatovenerology of the Clinical Hospital Centre in Zagreb (Figure 3).

The memorial collection of the Dogan Family became part of the collection of the Croatian Museum of Medicine and Pharmacy thanks to a donation from Branka Marinović, who on February 25, 2019 donated 74 items from the legacy of her father, neuropsychiatrist Sergije Dogan and her mother, pediatrician Kate Dogan-Librenjak. These are personal documents - school textbooks, student records, various documents and cards (19 items), diplomas and charters (34 items), as well as medals and plaques (21 items), of which 72 come are from Sergije Dogan, and two diplomas belonged to Kate Dogan-Librenjak.

Kate Dogan-Librenjak was born in 1923 in Dubrovnik and she graduated from the Zagreb School of Medicine in 1948. She specialized in pediatrics at the Clinical Hospital Centre Rebro, 


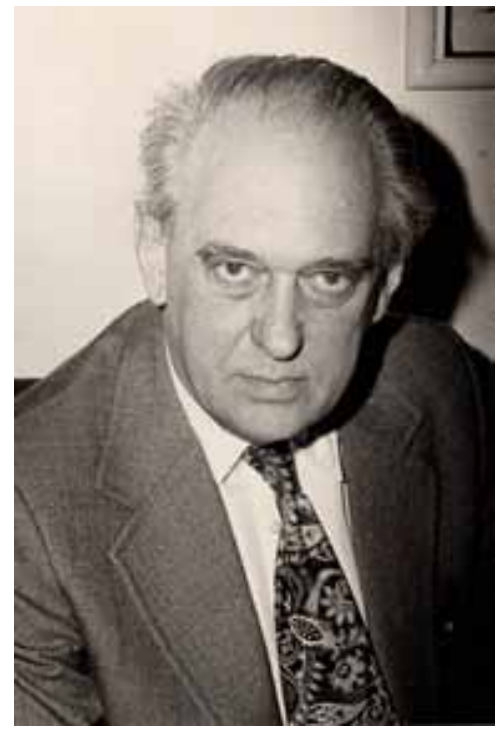

Figure 1. Sergije Dogan, photo taken in 1976, Division for the History of Medical Sciences, CASA

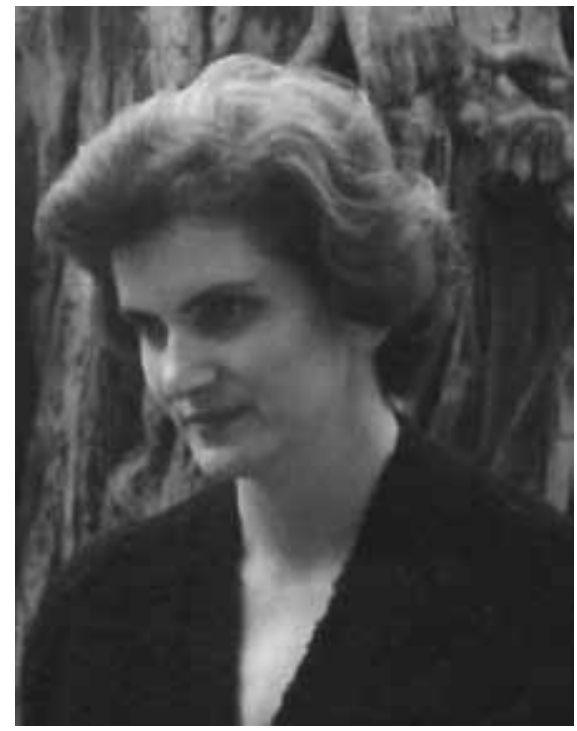

Figure 2. Kate Dogan-Librenjak, pediatrician, wife of Sergije Dogan, photo taken in 1961, private archive of Branka Marinovic

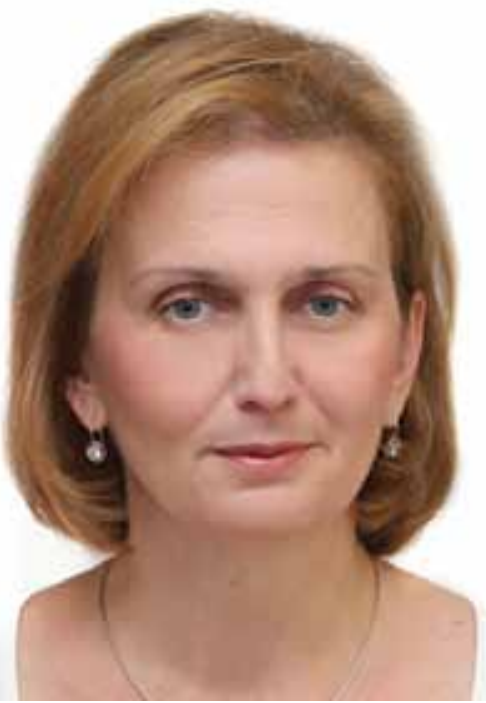

Figure 3. Branka Marinovic, the donor of the Dogan Legacy where she started working as a specialist for children. In 1960 she went to study in the USA, where she met Sergije Dogan and where they got married. Upon her return to Zagreb, she went on maternity leave and after that worked at the Hospital "Dr. Mladen Stojanović" (today Hospital of the Sisters of Charity), where she mostly dealt with pediatric gastroenterology, especially cystic fibrosis, which she had studied in the United States. She became the chief physician and head of the pediatric gastroenterology department of the said hospital. She died of cancer in 1979, a few months before her husband.

The donated material is a rare example of preserved material evidence of the entire course of education, clinical, scientific and teaching work of one doctor and his broader social activities. In addition to items from Dogan's legacy, which belong to the Museum, the Division for the History of Medical Sciences of the Croatian Academy of Sciences and Arts has preserved a collection of his offprints and other publications, his habilitation thesis, doctoral dissertation, some personal documentation related to

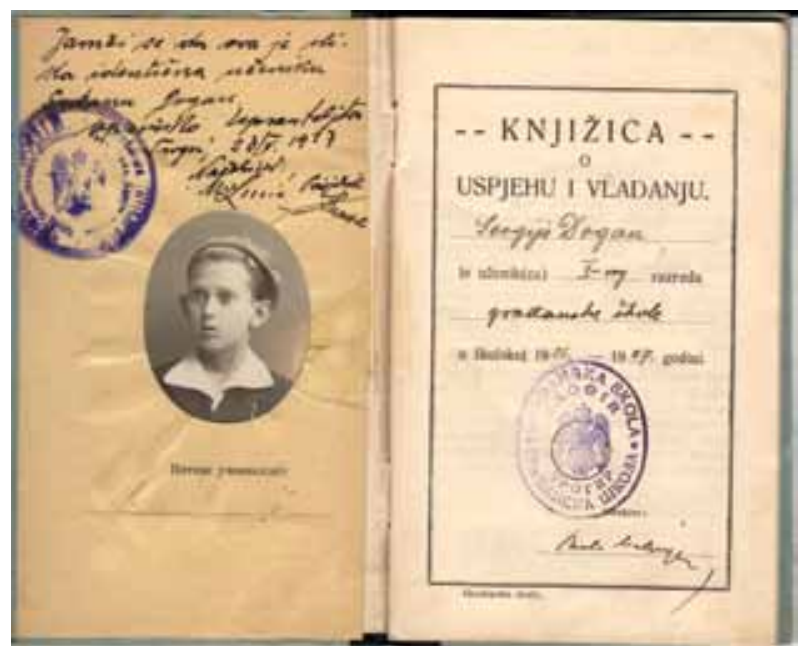

Figure 4. School records for Sergije Dogan's first grade of public school, Trogir, 1926/27, Croatian Museum of Medicine and Pharmacy, CASA the Zagreb School of Medicine and the Neurology Clinic, as well as a collection of newspaper clippings, also a gift from Branka Marinović. The overall legacy of this deserving Croatian doctor will be presented in full at the exhibition included in the Museum's program for 2021 and in the accompanying catalogue, while his role and contribution to the development of Croatian medical sciences will be presented in a book of the publishing series Discussions and Materials for the History of Science of the Croatian Academy of Sciences and Arts, which is scheduled for 2022. Neuropsychiatrist Sergije Dogan was born in 1916 in Šibenik. He attended primary school in Trogir, which he started in 1926/27. (Figure 4) He attended the State Classical Grammar School in Split and finished it in Šibenik, where he graduated on June 21, 1934. (Figure 5) He then left his home county and went to study medicine in Zagreb, where he graduated in 1940. (Figure 6) While still studying medicine, he enrolled in the psychology course at the Zagreb University Faculty of Philosophy, where he studied in the period from 1939 to 1941 . (Figure 7)

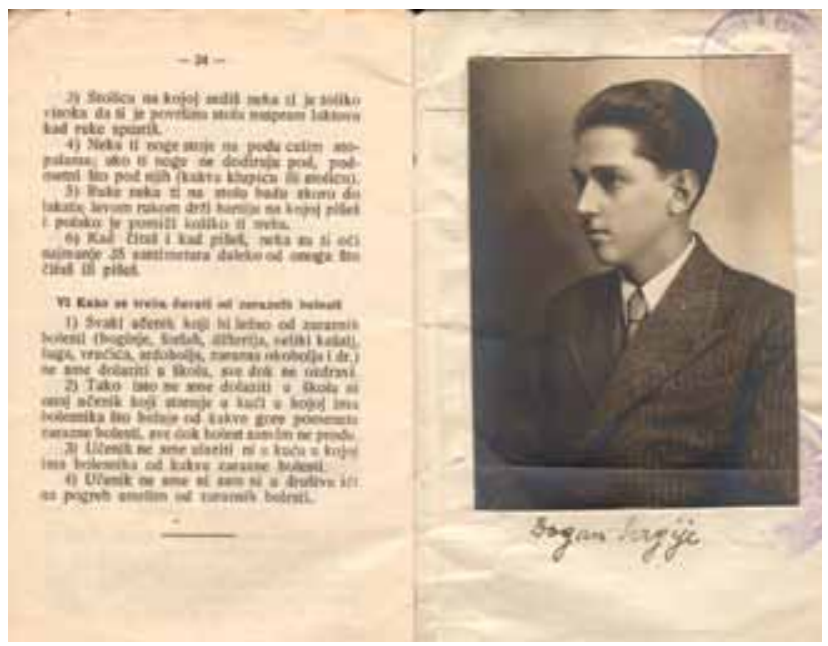

Figure 5. School records for Sergije Dogan as a graduate of the Classical Grammar School, Šbenik, 1933/34, Croatian Museum of Medicine and Pharmacy, CASA 


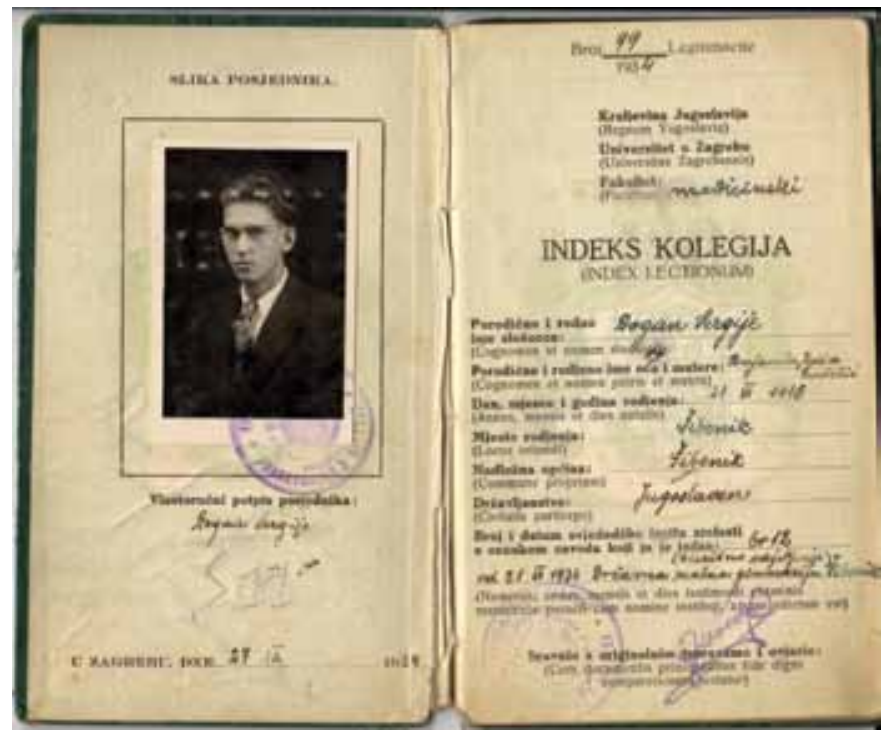

Figure 6. Sergije Dogan's University records, Zagreb, 1934, Croatian Museum of Medicine and Pharmacy, CASA

From 1941 he worked at the Clinic for Nervous and Mental Diseases in Zagreb, initially as a volunteer, where he specialized in neuropsychiatry and progressed from the title of assistant to head of department and then head of the neurology departments. Following a decision of the Ministry of Public Health of the Republic of Croatia, on 3 February 1949 he became a specialist in neurology and psychiatry. After receiving a scholarship from the World Health Organization, he trained at the Queen Square Institute of Neurology in London and the Karolinska University Hospital in Stockholm (1948-1949). There he was introduced with the development of new tendencies in clinical neurophysiology and, inspired by these novelties, he acquired the first electroencephalography machine in Croatia, which he began using in 1952. Such an innovative environment supported a surge of dynamic activity in the field of epilepsy, and at Dogan's initiative, an EEG device was constructed in Croatia, which soon began to be mass-produced so as to be available to other clinical centres in the country. Therefore, we consider Dogan to be the founder of Croatian clinical neurophysiology and the Epilepsy Station. In an effort to emphasize the historiographical accuracy of the founding of the Station, later the Centre for Epilepsy of the Neurology Clinic, Croatian neurologist and long-time associate of Sergije Dogan, Anica Jušić, said the following: "At this point I would like to emphasise several facts which have been neglected in recent historiography. It has been stated that the Centre for Epilepsy of the Neurology Clinic was founded in 1956, and Franjo Hajnšek is mentioned as its founder. ${ }^{13}$ The fact is that in 1956 Franjo Hajnšek had just completed his specialisation in neuropsychiatry and was appointed head of the EEG laboratory. It is also a fact that before him, the Station for Epilepsy was run by Vlado Rogina, aside from a lot of other work he was doing. He became a teaching assistant at university at the same time as Franjo Hajnšek and myself, except that I am two years younger than them, so they had already completed their specialization. The Station had already obtained the first EEG device, donated by UNRAE in 1952. Sergije Dogan and Petar Erak, a pediatrician, taught about epilepsy in 1953 as part of the then promoted popularization of science. I listened to them as a medi-

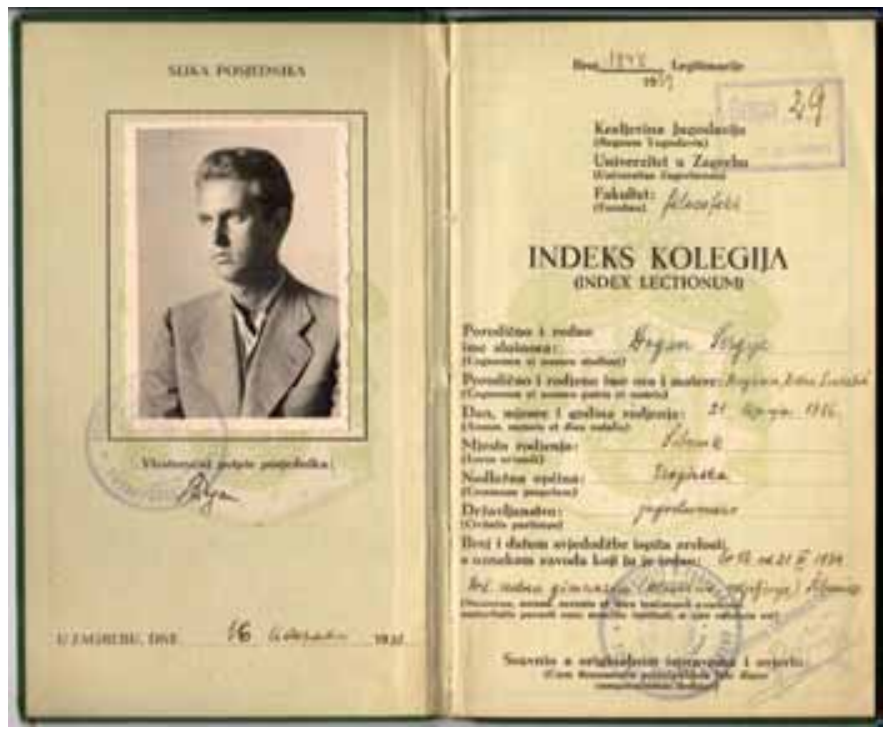

Figure 7. Sergije Dogan's University records for the psychology course, Zagreb, 1939, Croatian Museum of Medicine and Pharmacy, CASA

cal trainee. Thanks to Andrija Štampar, Sergije Dogan received scholarships in England and Sweden. In particular, he maintained contact with epileptologist Denis Williams from the Queen Square National Hospital in London. He successfully fought for the local production of EEG devices and definitely founded the Station by appointing the neuropsychiatry specialist Franjo Hajnšek as its chief. Therefore, the founder of the Station is undoubtedly Sergije Dogan." 14

In addition to working at the clinic, Dogan was actively involved in teaching. He compiled a neurology script for medical students (1950, 1951, 1954, 1961) and students of defectology (1969, 1971, 1975). Undoubtedly, he knew how to obtain quality communication with students, which was confirmed by the diploma of the Student Union of the Zagreb School of Medicine, awarded to him as a token of successful cooperation. (Figure 8)

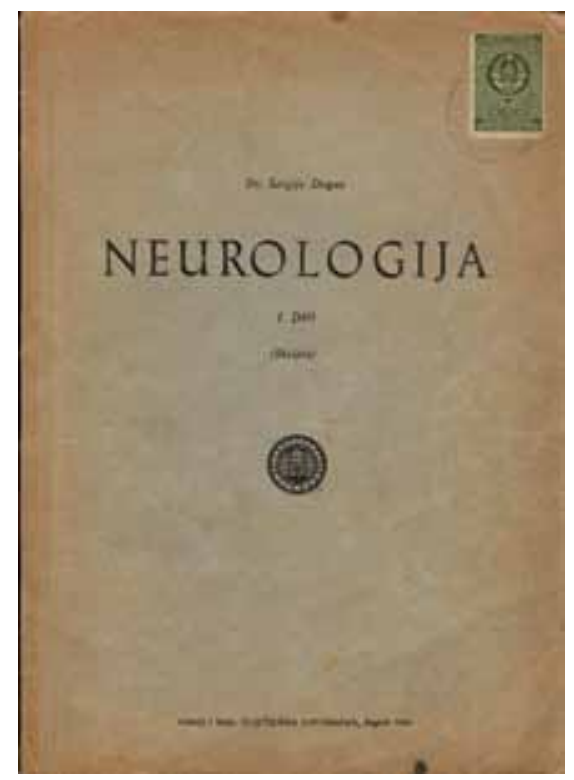

Figure 8. Sergije Dogan, neurology textbook, Zagreb, 1950, Division for the History of Medical Sciences, CASA 


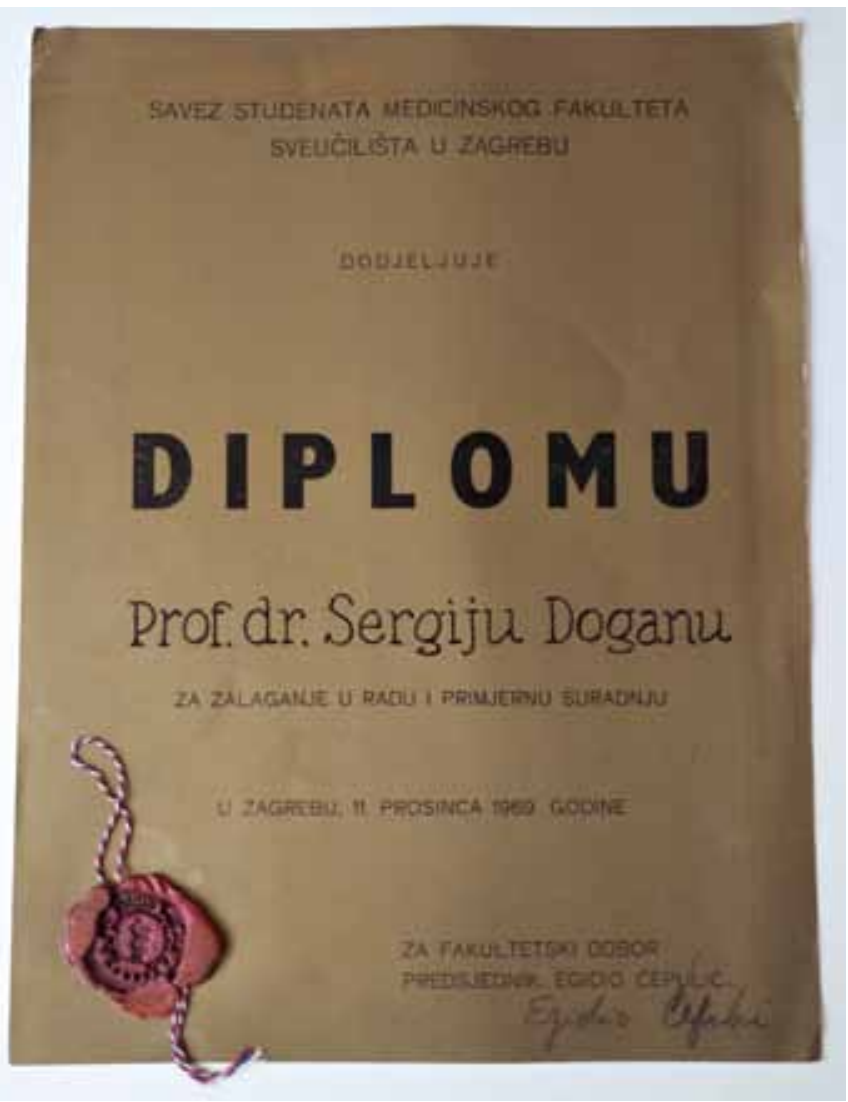

Figure 9. Diploma of the Zagreb School of Medicine Student Association to Sergije Dogan, 1969, Croatian Museum of Medicine and Pharmacy, CASA

Dogan became a private assistant professor at the Zagreb School of Medicine in 1952, and his habilitation thesis, which is kept at the Division for the History of Medical Sciences of the Croatian Academy of Sciences and Arts, is entitled Clinical significance of congenital anomalies in the area of the craniovertebral junction. Two years later, he was appointed assistant professor at the Department of Neurology and Psychiatry, then in 1958 an associate professor, and in 1965 a full-time professor. Interest in teaching, working with students and efforts to improve the quality of medical studies are reflected in the fact that from 1964 to 1966 he was the vice dean, and from 1966 to 1970 dean of the Zagreb School of Medicine, and twice president of the School's Council. Dogan was also an active member of the Croatian Medical Association, and in the period between 1958 and 1960 he was its president. He actively participated in the work of professional societies; he was the president of the Neurology Section of the Croatian Medical Association, the president of the League Against Epilepsy in Croatia and a member of the Academy of the Medical Association.

From 1960 to 1962 he trained at the University of Pennsylvania in Philadelphia, USA. In Philadelphia he worked with neurologist Solomon D. Erulkar and neurosurgeon Peter Jannet, and the results of their collaboration were published in the Journal of Neurophysiology in 1966. ${ }^{15}$ In 1967 he was invited by the French government to work in France, after which he went to Denmark

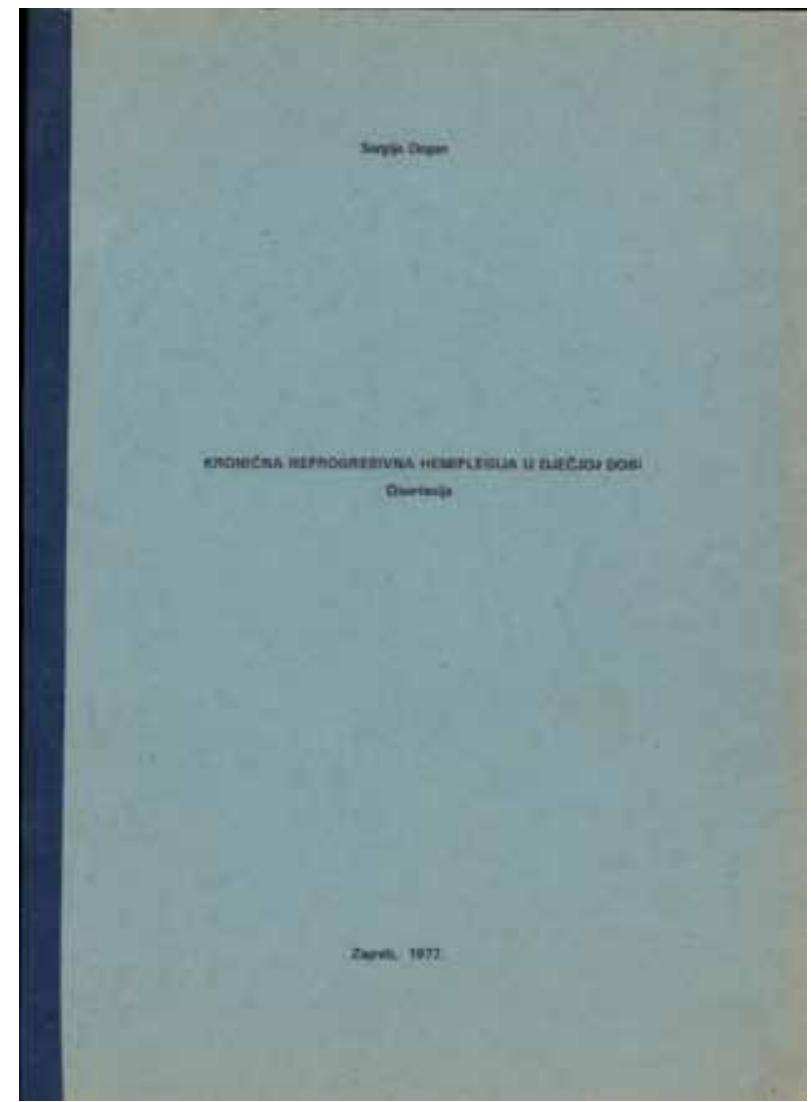

Figure 10. Sergije Dogan's docoral thesis, Zagreb, 1977, Division for the History of Medical Sciences, CASA

and Sweden. Furthermore, he continued his work in England and West Germany in 1971 through the World Health Organization funding, and in 1972 he returned to France.

Dogan ran the Neuropsychiatry Clinic in Zagreb from 1967 to 1971. For the sake of precision, it should be noted that in Dogan's time, neuropsychiatry was a unique kind of specialization, and the experts of the older generation were given the title specialist of neuropsychiatry. As the volume of knowledge of both specializations increased, they were separated in 1971, so that two clinics were formed at Rebro Hospital: the Clinic of Neurology within the Zagreb School of Medicine and the Clinical Hospital Centre in Zagreb, whose first chief was Sergije Dogan, and the Clinic of Psychiatry, whose first chief was Nikola Peršić. ${ }^{16,17}$ Under Dogan's leadership, the Clinic was reorganized so that functional departments, centres and specialised laboratories were formed. Dogan also founded and managed the Nervous System Research Unit. He obtained his doctorate in 1978 with a dissertation entitled Chronic Non-Progressive Hemiplegia in Children. ${ }^{18}$ For many years he was preoccupied with the problems of childhood neurology and was accordingly an advisor at the Department of Special Education and Rehabilitation and a teacher at the College of Special Education and Rehabilitation. In addition to specialised departments and laboratories, he encouraged and developed medical work related to extrapyramidal diseases, headaches and head trauma. ${ }^{19}$ 


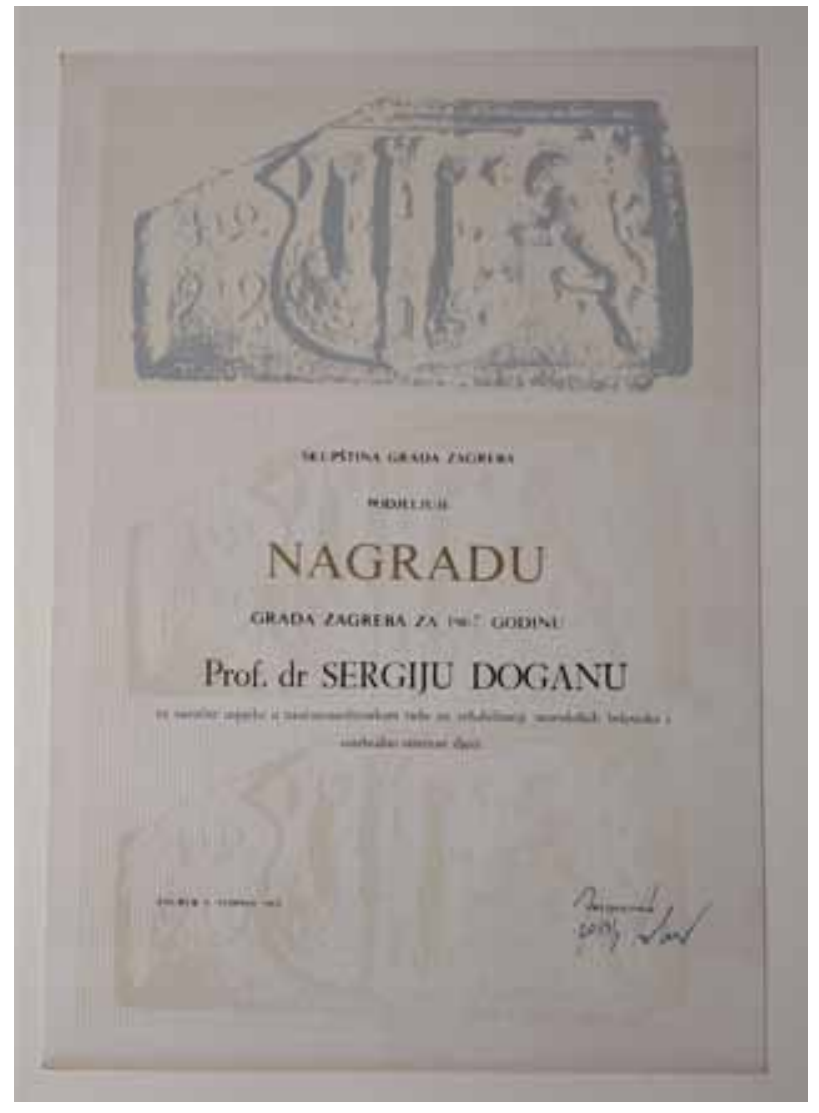

Figure 11. The Charter of the City of Zagreb Award to Sergije Dogan, 1967, Croatian Museum of Medicine and Pharmacy, CASA

He gathered around him a number of associates and encouraged the organization of the Symposium on Cerebrovascular Diseases, which, according to his colleague Nenad Grčević, played a major role in our region in raising the standards of diagnosis, therapy and scientific research in this important area. ${ }^{19}$

As the head of the Department of Neurology, he initiated a postgraduate study in neurology. He was one of the founders of the Institute for the Rehabilitation of Children with Cerebral Palsy at Goljak Hospital in Zagreb and the president of the Rehabilitation Committee of the State Secretariat for Health and Social Welfare of Croatia. He was the president of the publishing board of the journal Neurology, a permanent contributor to the Medical Encyclopedia, a corresponding member of the American Academy of

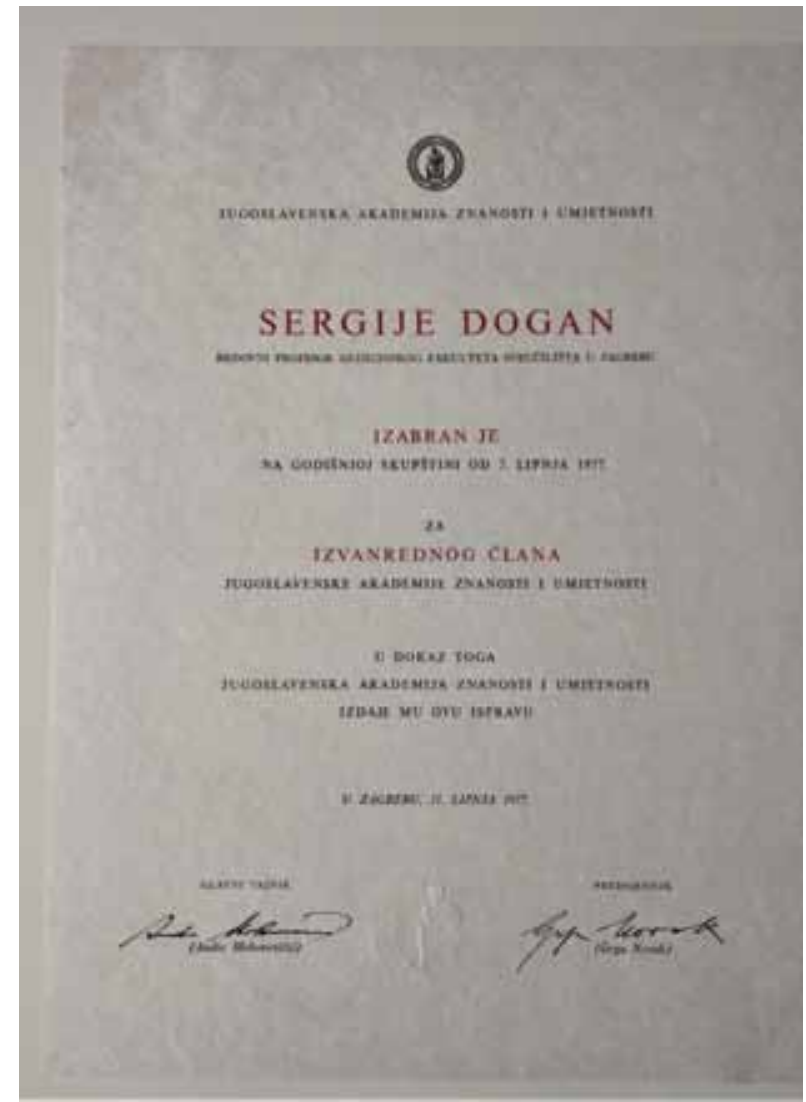

Figure 12. The Charter awarded to Sergije Dogan as an external member of the Yugoslav Academy of Sciences and Arts, JAZU, Zagreb, 1977, Croatian Museum of Medicine and Pharmacy, CASA

Cerebral Palsy, an honorary member of the French Neurology Society and winner of numerous awards and recognitions, of which we would like to emphasise the City of Zagreb Award. (Figure 9) In 1977 he was appointed external member of the Yugoslav Academy of Sciences and Arts (JAZU). ${ }^{20}$ (Figure 10)

He died unexpectedly in a car accident on April 17, 1979. Long after his death, his work continued to live in quotations of new generations of neurologists, in the memories of many of his associates, and thus it remained inscribed in the development and history of our eminent institutions. Finally, his legacy, which is today preserved in two of Academy's institutions, will certainly be positive motivation for future research, exhibitions, presentation and evaluation of the role of this prominent Croatian doctor. 


\section{LITERATURE:}

1. Fatović-Ferenčić S. Hrvatski muzej medicine i farmacije HAZU - od zbirke do muzeja u osnivanju. Vijesti muzealaca i konzervatora 2014:38-40.

2. Fatović-Ferenčić S, Brkić Midžić S. Sjećanje na prvi muzej medicine. Zagreb moj grad 2017;11(63):88-92.

3. Fatović-Ferenčić S. Od zbirke do Hrvatskog muzeja medicine i farmacije : povijest nastojanja vezanih uz realizaciju muzeja. Liječničke novine 2015;141(7-15):70-3

4. Brkić Midžić S. Novi muzej u sastavu Hrvatske akademije znanosti i umjetnosti - Hrvatski muzej medicine i farmacije. Glasnik HAZU 2016;2(3-4):42-5.

5. Brkić Midžić S. A New Museum within the Croatian Academy of Sciences and Arts and the First of the Kind in Croatia: the Croatian Museum of Medicine and Pharmacy. AMHA 2016;14(2):201-10.

6. Brkić Midžić S. Hrvatski muzej medicine i farmacije HAZU osnutak, poslanje i fundus. Medix 2020; 26(142):39-41.

7. Fatović-Ferenčić $S$, Brkić Midžić S, Kuhar M. Zapisnik o reviziji muzejske građe Hrvatskog muzeja medicine i farmacije HAZU, 20. ožujka 2020. (Documentation of the Croatian Museum of Medicine and Pharmacy, CASA).

8. Slavić T. Donacijom obitelji Gojmerac iz ostavštine Hrvoja Tartalje obogaćen fundus Hrvatskog muzeja medicine i farmacije HAZU. Farm Glas 2018;74(7-8):531-4.

9. Adžić V. Donacija iz ostavštine farmaceutske obitelji Efendić za Hrvatski muzej medicine i farmacije HAZU. Farm Glas 2017:73(7-8):535-40

10. Fatović-Ferenčić $S$. Od zbirke do Hrvatskog muzeja medicine i farmacije. Mef.hr 2015;34(2):155-7.
11. Fatović-Ferenčić S, Brkić Midžić S. Diplome i povelje hrvatskih farmaceuta iz zbirke Hrvatskog muzeja medicine i farmacije HAZU. Zagreb: Hrvatska akademija znanosti i umjetnosti : Hrvatsko farmaceutsko društvo; 2019.

12. Fatović-Ferenčić S, Brkić Midžić S. Tragom dviju ljekarničkih diploma - kronologija vlasništva najstarije sisačke ljekarne. Farm Glas 2019;75(7-8):529-46.

13. Barac B, Jadro-Šantel D, eds. Spomen-knjiga povodom 65. godišnjice osnivanja neurologije na Medicinskom fakultetu Sveučilišta u Zagrebu (1921. - 1986.). Zagreb; 1986, p. 9.

14. Pećina M, Fatović-Ferenčić S, eds. Dva života Anice Jušić. Razvoj neurologije i hospicijskog pokreta u Hrvatskoj tijekom druge polovine 20. stoljeća. Rasprave i građa za povijest znanosti, knjiga 13, sv. 9. Zagreb: HAZU; 2014., p. 13.

15. Erulkar SD, Sprague JM, Whitsel BL, Dogan S, Jannetta PJ: Organization of the Vestibular Projection to the Spinal Cord of the Cat. J. Neurophysiol. 1966;29:626-64.

16. Barac B. Neurološka i klinička neurofiziologija. Zdravstvo u socijalističkoj Republici Hrvatskoj. Razvoj, stanje, perspektive. In: Popović B, Letica S, Škrbić M, eds. Medicinske struke. Zagreb: JUMENA; 1981, p. 153.

17. Barac B. Osvrt na razvoj kliničke neurofiziologije u Hrvatskoj. Neuropsihijatrija 1974;22:163-8.

18. Dogan S. Kronična neprogresivna hemiplegija u dječjoj dobi. Zagreb: Medicinski fakultet; 1977.

19. Grčević N. Sergije Dogan, 1916-1979. Spomenica preminulim akademicima. Zagreb: JAZU; 1981;14:14.

20. Dugački V. Dogan, Sergije. Hrvatski biografski leksikon. Sv. 3. Zagreb: Leksikografski zavod Miroslav Krleža; 1993., pp. 453-454. 
